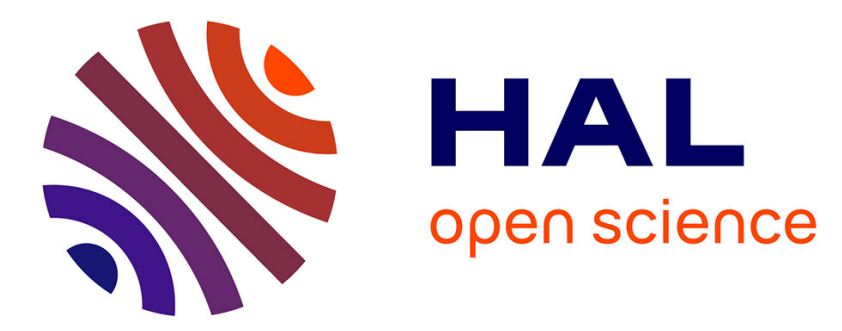

\title{
Metabolic-dependent changes in plant cell redox power after ozone exposure
}

\author{
Pierre Dizengremel, Didier Le Thiec, Marie-Paule Hasenfratz-Sauder, \\ Marie-Noëlle Vaultier, Matthieu Bagard, Yves Jolivet
}

\section{- To cite this version:}

Pierre Dizengremel, Didier Le Thiec, Marie-Paule Hasenfratz-Sauder, Marie-Noëlle Vaultier, Matthieu Bagard, et al.. Metabolic-dependent changes in plant cell redox power after ozone exposure. Plant Biology, 2009, 11 (suppl. 1), pp.35-42. 10.1111/j.1438-8677.2009.00261.x . bioemco-00458112

\section{HAL Id: bioemco-00458112 https://hal-bioemco.ccsd.cnrs.fr/bioemco-00458112}

Submitted on 31 May 2020

HAL is a multi-disciplinary open access archive for the deposit and dissemination of scientific research documents, whether they are published or not. The documents may come from teaching and research institutions in France or abroad, or from public or private research centers.
L'archive ouverte pluridisciplinaire HAL, est destinée au dépôt et à la diffusion de documents scientifiques de niveau recherche, publiés ou non, émanant des établissements d'enseignement et de recherche français ou étrangers, des laboratoires publics ou privés. 


\title{
Metabolic-dependent changes in plant cell redox power after ozone exposure
}

\author{
P. Dizengremel ${ }^{1,2}$, D. Le Thiec ${ }^{1,2}$, M.-P. Hasenfratz-Sauder ${ }^{1,2}$, M.-N. Vaultier ${ }^{1,2}$, M. Bagard ${ }^{1,2}$ \& \\ Y. Jolivet ${ }^{1,2}$ \\ 1 Nancy-Université, UMR 1137 Ecologie et Ecophysiologie Forestières, Vandoeuvre-lès- Nancy, France \\ 2 INRA, UMR 1137 Ecologie et Ecophysiologie Forestières, Champenoux, France
}

Keywords

Detoxification; effective dose; indicator of risk; NADP-dependent enzymes; ozone uptake; reducing power.

\author{
Correspondence \\ P. Dizengremel, Nancy-Université, UMR 1137 \\ Ecologie et Ecophysiologie Forestières, 54506 \\ Vandoeuvre-lès- Nancy, France. \\ E-mail: Pierre.Dizengremel@scbiol. \\ uhp-nancy.fr \\ Editor \\ L. De Kok \\ Conflicts of interest \\ The authors have declared no conflicts of \\ interest. \\ Received: 25 March 2009; Accepted: 11 \\ August 2009 \\ doi:10.1111/j.1438-8677.2009.00261.x
}

\begin{abstract}
The tropospheric level of the phytotoxic air pollutant ozone has increased considerably during the last century, and is expected to continue to rise. Long-term exposure of higher plants to low ozone concentrations affects biochemical processes prior to any visible symptoms of injury. The current critical level of ozone used to determine the threshold for damaging plants (biomass loss) is still based on the seasonal sum of the external concentration above $40 \mathrm{nl} \cdot \mathrm{l}^{-1}$ (AOT40). Taking into account stomatal conductance and the internal capacity of leaf defences, a more relevant concept should be based upon the 'effective ozone flux', the balance between the stomatal flux and the intensity of cellular detoxification. The large decrease in the Rubisco/PEPc ratio reflects photosynthetic damage from ozone, and a large increase in activity of cytosolic PEPc, which allows increased malate production. Although the direct detoxification of ozone (and ROS produced from its decomposition) is carried out primarily by cell wall ascorbate, the existing level of this antioxidant is not sufficient to indicate the degree of cell sensitivity. In order to regenerate ascorbate, $\mathrm{NAD}(\mathrm{P}) \mathrm{H}$ is needed as the primary supplier of reducing power. It is hypothesised that increased activity of the catabolic pathways and associated shunts (glucose-6-phosphate dehydrogenase, NADP-dependent glyceraldehyde-3-phosphate dehydrogenase, isocitrate dehydrogenase and malic enzyme) can provide sufficient $N A D(P) H$ to maintain intracellular detoxification. Thus, measurement of the level of redox power would contribute to determination of the 'effective ozone dose', serving ultimately to improve the ozone risk index for higher plants.
\end{abstract}

\section{INTRODUCTION}

Tropospheric ozone is a pollutant that harms plants (Matyssek \& Innes 1999; Krupa et al. 2001; Ashmore 2005; Karnosky et al. 2007; Wittig et al. 2009). The phytotoxicity of ozone is determined in several successive steps: (i) concentration of the pollutant in the external atmosphere surrounding leaves; (ii) deposition of ozone to soil and plant surfaces, especially leaves; (iii) degree of uptake of ozone within leaves through stomata; and (iv) level of antioxidants counteracting the oxidative attack. Measurement of ambient ozone concentrations in air (step 1) has been used to define different critical levels, based on long-term cumulative exposure. The AOT 40 concept (sum of hourly ozone concentrations above a threshold of $40 \mathrm{n} \cdot \mathrm{l}^{-1}$ during daylight hours of the growing season) is the reference parameter used within Europe (Fuhrer et al. 1997). Other measures of ozone exposure, such as the SUM06 (sum of all hourly average concentrations over $0.06 \mathrm{ppm}$ ) or the sigmoidally weighted W126 exposure index used in North America (Lefohn et al. 1988) are also available. Concentration-based concepts, however, ignore the real flux of ozone through stomata, which is influenced by deposition of ozone on different surfaces including leaf cuticles (step 2) and uptake through stomata (step 3), both of which depend on 
climatic conditions. The direct harmful effects of ozone on leaves thus depend on the stomatal flux of ozone, which integrates parameters linked to stomatal conductance (Ashmore et al. 2004; Grünhage et al. 2004; Karlsson et al. 2004; Gerosa et al. 2009). The degree of stomatal opening is, however, not necessarily the only factor conferring sensitivity or tolerance to ozone stress.

After penetrating leaves (Fig. 1), gaseous ozone dissolves in the apoplasm, giving rise to reactive oxygen species (ROS) such as $\mathrm{O}_{2}{ }^{-}, \mathrm{H}_{2} \mathrm{O}_{2}$ and $\mathrm{OH}$. (Byvoet et al. 1995). A range of antioxidant metabolites and detoxifying processes that can scavenge ROS (step 4) is present, and apoplastic ascorbate appears the best candidate as a first line of defence (Plöchl et al. 2000). The presence of a high level of apoplastic ascorbate, however, is not always sufficient to counteract the toxicity of ROS (Ranieri et al. 1999; Conklin \& Barth 2004; D'Haese et al. 2005). Apoplastic ascorbate must be regenerated via intracellular detoxifying pathways, and the rate of regeneration controls the 'effective ozone flux', corresponding to the non-detoxified ozone molecules (Matyssek et al. 2004; Musselman et al. 2006; Paoletti \& Manning 2007; Tausz et al. 2007; Wieser \& Matyssek 2007; Dizengremel et al. 2008). This scenario would be valid if realistic concentrations of ozone are chronically delivered and must be adjusted in the case of short-term acute exposure (Renaut et al. 2009). This review highlights ways in which cellular metabolism creates conditions that allow reducing power to play a prominent role in keeping antioxidant levels high.

\section{Effective ozone flux and detoxification power}

The 'effective ozone flux' concept is based on a balance between stomatal flux and leaf cellular detoxification. The degree of stomatal opening controls the quantity of ozone molecules entering the leaf and subsequently being converted to ROS. Ozone itself can trigger the activity of a plasma membrane NADPH oxidase delivering the superoxide ion (Langebartels et al. 2002). On the other hand, even though representing a small percentage of total superoxide dismutase (SOD), an apoplastic $\mathrm{Cu}-\mathrm{Zn}$ SOD could scavenge, at least in part, the superoxide ion (Schinkel et al. 1998; Srivastava 1999). The main level of defence relies both on the existing content of cellular antioxidants (e.g. ascorbate) and intensity of the detoxifying processes regenerating these metabolites. A specific pool of apoplastic ascorbate is thought to react directly with ozone and ROS (Polle et al. 1995; Luwe 1996; Turcsanyi et al. 2000). However, the apoplasm can be easily and rapidly depleted of ascorbate, allowing the subsequent oxidative action of ROS in foliar cells (Zheng et al. 2000; van Hove et al. 2001). An efficient protective mechanism would require the transfer of ascorbate from intracellular detoxifying systems to the cell wall. The detoxification processes thus elicited must be able to cope with this increased demand. Increases in antioxidant enzyme activities [SOD, ascorbate peroxidase (APX), glutathione reductase (GR)] have been observed in a large number of ozone fumigation experiments (Tandy et al. 1989; Sen Gupta et al. 1991; Wingsle et al. 1992; Pitcher \& Zilinskas 1996; Sehmer et al. 1998; Srivastava 1999). These changes are often linked to parallel changes in gene expression (Willekens et al. 1994; Gupta et al. 2005; Heath 2008). However, while a general increase in antioxidant defences usually follows ozone attack, the degree of sensitivity of foliar cells will depend on equilibrium between the importance of the raised detoxifying barrier and the degree of stomatal ozone uptake (Di Baccio et al. 2008). A good indicator of sensitivity would thus be the potential detoxification capacity estimated per unit of ozone influx (Di Baccio et al. 2008; Matyssek et al. 2008).

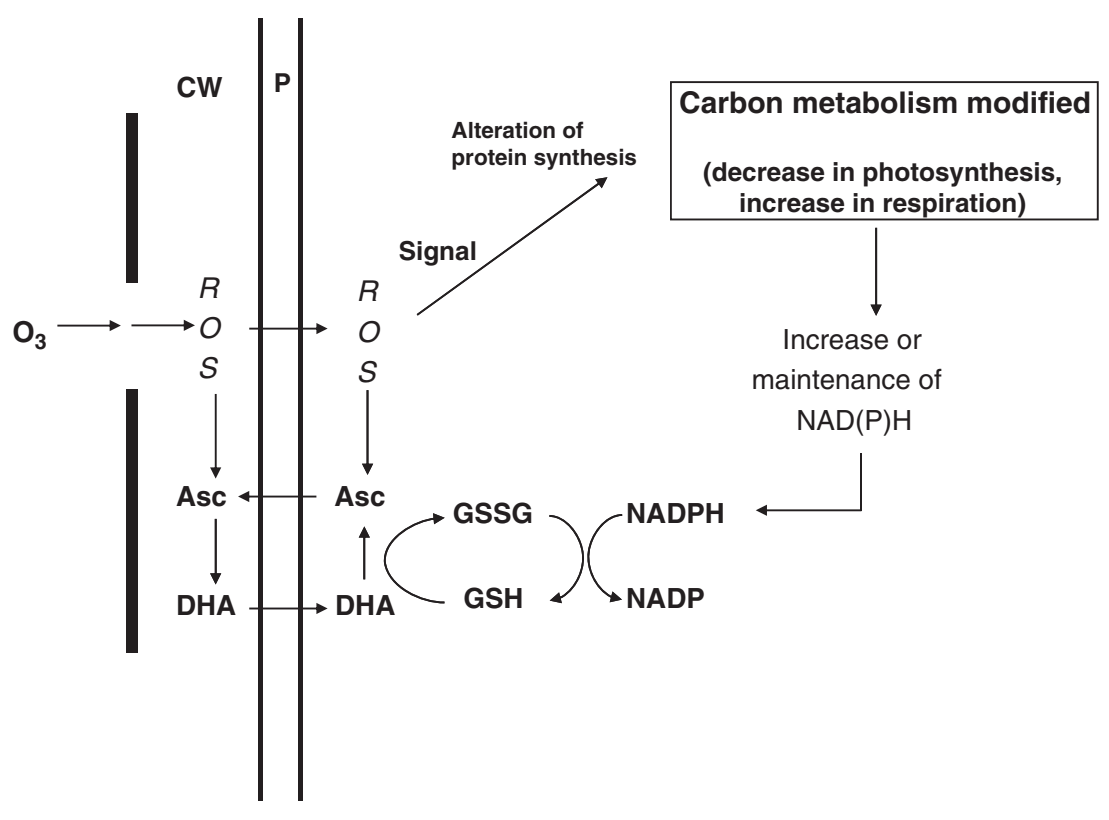

Fig. 1. Dual effect of ozone-induced ROS on the detoxification process and metabolic regeneration of reducing power. Asc = ascorbate; CW = cell wall; $\mathrm{DHA}=$ dehydroascorbate; GSH/GSSG = reduced/oxidised glutathione; $\mathrm{P}=$ plasma membrane; $\mathrm{ROS}=$ reactive oxygen species. 
Regeneration of the reduced forms of ascorbate and glutathione can be provided by enzymes using the reducing power of $\mathrm{NAD}(\mathrm{P}) \mathrm{H}$. These soluble redox molecules appear to play a central role in establishment of antioxidant defence mechanisms (Noctor 2006; Dizengremel et al. 2008).

\section{Ozone uptake and changes in carbon fixation}

Plant cells perceive the presence of ozone and associated ROS as an 'oxidative signalling' stimulus. This has been documented to cause carbon metabolism changes and associated alteration in gene expression (Dizengremel 2001; Foyer \& Noctor 2005; Heath 2008; Renaut et al. 2009). The effect of ozone in decreasing the photosynthetic rate relates to a corresponding decrease in activity of Rubisco, as observed in various plant species (Pell et al. 1992; Dizengremel et al. 1994; Dizengremel 2001; Gaucher et al. 2003; Inclan et al. 2005; Wittig et al. 2007; Bagard et al. 2008). This ozone-induced decrease in Rubisco activity is linked to a decrease in Rubisco quantity, which could involve both an increased rate of protein degradation and an inhibition of protein synthesis (Brendley \& Pell 1998; Pell et al. 1999; Junqua et al. 2000; Dizengremel 2001; Pelloux et al. 2001; Gupta et al. 2005;

Table 1. Rubisco and PEPc activities (in nkat $\mathrm{mg}^{-1}$ protein) and ratios of the two carboxylases in leaves of trees submitted to chronic ozone exposure in phytotron chambers. (C) control; $\left(\mathrm{O}_{3}\right)$ ozone-fumigated.

\begin{tabular}{|c|c|c|c|c|c|c|}
\hline & \multicolumn{2}{|c|}{ Rubisco } & \multicolumn{2}{|l|}{ PEPC } & \multicolumn{2}{|c|}{$\begin{array}{l}\text { Rubisco/ } \\
\text { PEPc ratio }\end{array}$} \\
\hline & $C$ & $\mathrm{O}_{3}$ & C & $\mathrm{O}_{3}$ & C & $\mathrm{O} 3$ \\
\hline \multicolumn{7}{|c|}{ Norway spruce ${ }^{a}$} \\
\hline Gerardmer & 12.8 & 6.0 & 0.50 & 5.40 & 25.6 & 1.11 \\
\hline Istebna & 13.2 & 6.2 & 0.45 & 2.55 & 29.3 & 2.43 \\
\hline Aleppo pine ${ }^{b}$ & 13.6 & 7.5 & 0.55 & 1.96 & 24.7 & 3.82 \\
\hline Poplar & 17.0 & 9.1 & 0.36 & 1.35 & 47.2 & 6.74 \\
\hline Beech $^{d}$ & 9.2 & 4.65 & 1.33 & 1.81 & 6.9 & 2.56 \\
\hline Sugar maple & 2.56 & 1.76 & 0.75 & 1.73 & 3.4 & 1.01 \\
\hline
\end{tabular}

${ }^{a}$ Antoni 1994. Three-year-old Norway spruce (Picea abies; Gerardmer and Istebna clones) submitted to $\left.200 \mathrm{nl} \cdot\right|^{-1} \mathrm{O}_{3}$ during the photoperiod for 3 months. Measurements were made at the end of the experiment.

${ }^{b}$ Fontaine et al. 1999. Three-year-old Aleppo pine (Pinus halepensis) exposed to $200 \mathrm{nl} \cdot \mathrm{I}^{-1} \mathrm{O}_{3}$ during the photoperiod for 3 months. The activities were measured on day 34 .

'Deschaseaux 1997. Hybrid poplar (Populus tremula $\times$ alba) cuttings exposed to $60 \mathrm{n} \cdot \cdot^{-1} \mathrm{O}_{3}$ during the photoperiod for 1 month. Activities were measured after 2 weeks of fumigation.

dütz et al. 2000. Three-year-old beech (Fagus sylvatica) exposed for 4 months to $2 \times$ ambient $\mathrm{O}_{3}$ concentration (up to $110 \mathrm{nl} \cdot \mathrm{I}^{-1}$ ). Measurements were made after 3 months.

'Gaucher et al. 2003. Forty-five-day-old sugar maple seedlings (Acer saccharum) were fumigated with $200 \mathrm{nl} \cdot \cdot^{-1} \mathrm{O}_{3}$ during the photoperiod for 2 months. Measurements were made at the end of the experiment.
Matyssek et al. 2006; Bohler et al. 2007; Heath 2008). In $\mathrm{C}_{3}$ plants, the carboxylating enzyme is Rubisco in chloroplasts, while phosphoenolpyruvate carboxylase (PEPc) refixes respiratory $\mathrm{CO}_{2}$ in the cytosol. In the presence of ozone, Rubisco activity decreases, while a strong increase in activity of PEPc is observed (Landolt et al. 1994, 1997; Sehmer et al. 1998; Fontaine et al. 1999; Lütz et al. 2000; Gaucher et al. 2003; Inclan et al. 2005; Leitao et al. 2008; Renaut et al. 2009). Table 1 shows the opposite effect of chronic doses of ozone on the ratio between the two carboxylases for several species. The Rubisco/PEPc ratio decreases between three- and twentyfold (Table 1). This contrasting behaviour of the two carboxylases was observed in field studies where needles of declining trees in ozone-polluted areas had a lower Rubisco/PEPc ratio compared with that measured for needles from healthy trees (Wild \& Schmitt 1995; Dalstein et al. 2002). The increase in PEPc activity is clearly linked to an increase in the quantity of PEPc protein and of the corresponding mRNAs (Dizengremel 2001; Fontaine et al. 2003; Matyssek et al. 2006). PEPc could, under chronic ozone constraint, contribute to an anapleurotic pathway accounting for the replenishment of the mitochondrial Krebs cycle via oxaloacetate (or malate), as previously suggested (Dizengremel 2001).

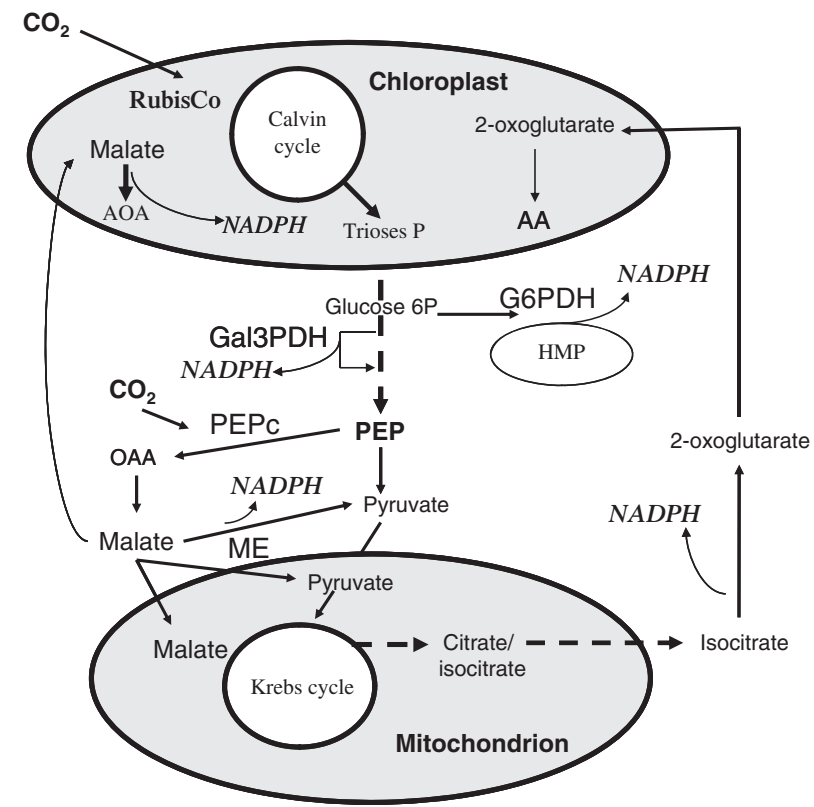

Fig. 2. Enzymes and associated pathways contributing to the supply of NADPH. $A A=$ amino acids; Gal3PDH = NAD(P)-dependent glyceraldehyde-3-phosphate dehydrogenase; G6PDH = glucose-6-phosphate dehydrogenase; $\mathrm{HMP}=$ hexose monophosphate pathway; $\mathrm{IDH}=$ NADP-dependent isocitrate dehydrogenase; $M E=$ NADP-dependent malic enzyme; $\mathrm{OAA}=$ oxaloacetic acid; $\mathrm{PEPC}=$ phosphoenolpyruvate carboxylase. 
Ozone, pathways of carbohydrate breakdown and reducing power

The anapleurotic pathway, after replenishment of the mitochondrial Krebs cycle, provides precursors for amino acid synthesis (Stitt 1999). This pathway uses citrate (or isocitrate) exported from this cycle to produce 2-oxoglutarate in the cytosol through an NADP-dependent isocitrate dehydrogenase (NADP-IDH) delivering NADPH (Chen \& Gadal 1990; Fig. 2). Cytosolic NADP-IDH has been suggested to play a role in plant defence against oxidative stress by delivering NADPH (Hodges et al. 2003; Leterrier et al. 2007). An increase in activity of NADPIDH has been measured in two tree species under ozone fumigation (Table 2) (Citerne et al. 1989; Fontaine 1999), which reinforces this hypothesis. The anapleurotic pathway also serves as a donor of malate directly in the cytosol to produce pyruvate and to provide NADPH through the NADP-malic enzyme (NADP-ME). Cytosolic NADPME has been linked to stress responses (Drincovich et al. 1998; Müller et al. 2008) and an increase in activity of this enzyme has been observed under ozone treatment (Table 2) (Fontaine 1999). Since respiration is generally increased by ozone (Dizengremel \& Petrini 1994; Dizengremel 2001), enhancement of both the glycolysisKrebs cycle and pentose phosphate pathway is expected. The most striking effect of ozone is increased activity of glucose-6-phosphate dehydrogenase $(\mathrm{G} 6 \mathrm{PDH})$ in various tree species, which can contribute to increased NADPH content (Citerne et al. 1989; Antoni 1994; Dizengremel et al. 1994; Sehmer et al. 1998; Fontaine 1999; Gaucher et al. 2003). The two main glycolytic enzymes, phosphofructokinase (PFK) and pyruvate kinase (PK), are also involved in a general increase of catabolism (Table 2) (Antoni 1994; Dizengremel et al. 1994; Sehmer et al. 1998; Fontaine 1999). In mitochondria, fumarase and NAD-malic enzyme (NAD-ME) activities increase with ozone exposure (Table 2) (Citerne et al. 1989; Antoni 1994; Dizengremel \& Petrini 1994; Dizengremel et al. 1994; Gérant et al. 1996; Sehmer et al. 1998; Fontaine 1999). A set of three cytosolic enzymes (G6PDH, NADPIDH, NADP-ME) is especially interesting as they provide $\mathrm{NADPH}$ in the cytosol, assisting ozone detoxification (Dizengremel et al. 2008). Another cytosolic enzyme, the non-phosphorylating NADP-dependent glyceraldehyde-3phosphate dehydrogenase (NADP-Gal3PDH), has been

Table 2. Effect of chronic ozone exposure on the activities (in nkat. $\mathrm{mg}^{-1}$ protein) of enzymes belonging to different catabolic pathways.

\begin{tabular}{|c|c|c|c|c|c|c|c|}
\hline & \multicolumn{2}{|c|}{ Glycolysis } & \multirow{2}{*}{$\frac{\text { HMP Pathway }}{\text { G6PDH }}$} & \multicolumn{2}{|l|}{ Cytosol } & \multicolumn{2}{|c|}{ Mitochondria } \\
\hline & PFK & PK & & NADP-ME & NADP-IDH & Fumarase & NAD-ME \\
\hline \multicolumn{8}{|c|}{ Norway spruce (clone Gerardmer) } \\
\hline OTC $^{a}$ & & & $\times 1.43$ & & $\times 1.06$ & $\times 2.07$ & $\times 1.20$ \\
\hline Phytotron $^{b}$ & $\times 1.80$ & & $\times 5.40$ & & & $\times 2.52$ & \\
\hline Beech $(\mathrm{OTC})^{\mathrm{c}}$ & $\times 1.06$ & & $\times 1.80$ & & & $\times 1.23$ & \\
\hline \multicolumn{8}{|l|}{ Loblolly pine (OTC) $)^{d}$} \\
\hline current-year & $\times 1.20$ & & $\times 1.18$ & & & $\times 1.06$ & $\times 1.16$ \\
\hline 1-year-old & $\times 1.22$ & & $\times 1.28$ & & & $\times 1.09$ & $\times 1.07$ \\
\hline \multicolumn{8}{|l|}{ Aleppo pine (phytotron) ${ }^{\mathrm{e}}$} \\
\hline current-year & & $\times 1.48$ & $\times 1.25$ & & $\times 1.42$ & & $\times 1.35$ \\
\hline 1-year-old & & $\times 2.70$ & & $\times 2.30$ & & & $\times 2.10$ \\
\hline 1-year-old ${ }^{f}$ & & & & & & & $\times 1.31$ \\
\hline Sugar maple (phytotron) ${ }^{g}$ & & & $\times 2.05$ & & & & \\
\hline Poplar (phytotron) ${ }^{\mathrm{h}}$ & & $\times 3.66$ & & $\times 2.36$ & & $\times 1.96$ & $\times 1.56$ \\
\hline
\end{tabular}

asix-month-old spruce seedlings were fumigated from spring 1985 in open-top chambers (OTC) with ambient ozone concentrations. Measurements were made on current year needles in November 1987 (Citerne et al., 1989).

${ }^{\mathrm{b}}$ Three-year-old spruce trees were fumigated in phytotronic chambers for 3 months with $200 \mathrm{~nL} . \mathrm{L}^{-1}$ ozone. Measurements were made on current-year needles at the end of the experiment (Sehmer et al., 1998).

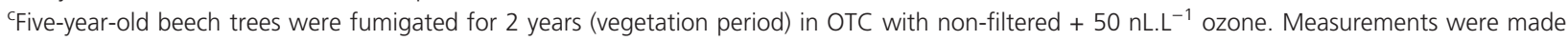
in summer, at the end of the treatment (Antoni, 1994).

dOne-year-old loblolly pine trees were fumigated in OTC with $2 \times$ ambient ozone concentration (12h daily mean ozone concentration of 86 $\mathrm{nL} . \mathrm{L}^{-1}$ ). Measurements were made in summer on current-year and 1-year old needles, the third growing season of exposure (Dizengremel et al., 1994; Dizengremel and Pétrini, 1994).

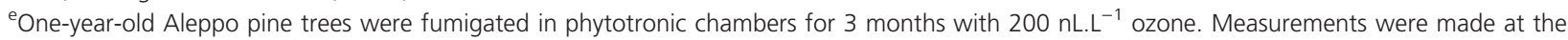
end of the experiment on current-year and 1-year old needles (Fontaine, 1999).

${ }^{\mathrm{f}}$ Three-year-old Aleppo pine trees were fumigated in phytotronic chambers for 3 months with $200 \mathrm{~nL} . \mathrm{L}^{-1}$ ozone. Measurements were made at the end of the experiment on 1-year old needles (Gérant et al., 1996).

${ }^{g}$ Forty-five-day-old sugar maple seedlings were fumigated in phytotronic chambers for 2 months with $200 \mathrm{~nL} . \mathrm{L}^{-1}$ ozone. Measurements were made at the end of the experiment (Gaucher et al., 2003).

${ }^{\mathrm{h}}$ Two months old poplar seedlings were fumigated in phytotronic chambers during 1 month with $100 \mathrm{~nL} . \mathrm{L}^{-1}$ ozone (Dizengremel and Jolivet, 2000, unpublished data). 
implicated in coping with oxidative stress (Bustos et al. 2008) and also needs to be studied (Fig. 2).

\section{Reducing power and threshold for ozone risk to plant cells}

In addition to deposition on cuticles, ozone molecules enter leaves through the stomata. Some molecules can then impair membranes of mesophyll cells (the fate of guard cells is still largely debated) while others and/or $\mathrm{O}_{3}$-derived ROS could be destroyed by apoplastic ascorbate. When ROS formation exceeds the antioxidant capacity of cells, ROS can play a dual role, directly oxidising the detoxifying systems in chloroplasts and cytosol and inducing a chain of signal messengers leading to changes in gene expression (Sandermann et al. 1998; Dizengremel 2001; Rao \& Davis 2001; Foyer \& Noctor 2005; Kangasjärvi et al. 2005; Heath 2008). The photosynthetic machinery is one of the first targets of ROS. The Calvin cycle, through the oxidation of the Rubisco protein and the repression of its synthesis, is damaged before any impairment of the light reactions (Dizengremel 2001; Heath 2008). An over-reduction of stromal compounds takes place transiently, with NADPH allowing the functioning of the Halliwell-Asada pathway. A possible transfer of excess NADPH in the cytosol by a malateoxaloacetate shuttle could also transiently occur (Scheibe 2004). NADPH export stops when the photosystems are damaged.

In parallel with the above reactions, there is a general increase in activity of catabolic pathways, with a particular emphasis on the huge rise in PEPc activity and synthesis (Fontaine et al. 2003). An unavoidable lack of carbon compounds, needed for repair and growth, may result. However, before falling inexorably towards death, cells typically activate an antioxidant defence mechanism. A possible signal could be the increase in PEPc activity, which allows the provision of malate through this shunt of glycolysis, and thus starts the anapleurotic pathway. Malate is known to play a central role in plant cell metabolism, and an increase in its quantity could directly provide additional NADPH through the NADP-ME pathway. Another possible role for malate is in continuation of the anapleurotic pathway by transfer of malate to mitochondria, where it participates in the Krebs cycle (Fig. 2). Citrate or isocitrate are subsequently transferred to the cytosol, where 2-oxoglutarate and NADP-IDH are produced (Fig. 2). In both cases, malate stimulates production of NADPH, which is useful for the ascorbate/glutathione reducing system. Finally, a provocative hypothesis is that malate enters the chloroplast, where it is oxidised by malate dehydrogenase (MDH) to produce $\mathrm{NADPH}$ to restore (at least in part) intra-chloroplastic reducing power (Fig. 2) Malate could thus play a central role to balance cellular energy supply between compartments (Scheibe 2004).

Other sources of cytosolic NADPH co-exist in the form of NADP-glyceradehyde-3-phosphate dehydrogenase (another shunt of glycolysis) and G6PDH (hexose mono- phosphate pathway). The observed increases in activity of this set of enzymes with ozone exposure could be related to a modification of the enzyme itself (NADP-Gal3PDH) or activation of transcriptional regulation. The question arises as to whether all these systems equally contribute to the NADPH supply, or whether there is a hierarchical system favouring one of the above systems. New experimental data will, hopefully, allow for a definition of the ratio between reduced and oxidised forms of pyridine nucleotides beyond a value where damage is irreversible. This breaking point should be used in a cellular model of effective ozone flux, which should be integrated into a global model to improve prediction of ozone risk for plant growth. The ultimate goal of this approach is to enhance estimation of the environmental and economic consequences of tropospheric ozone to plants.

\section{ACKNOWLEDGEMENTS}

This work was partly supported by the programmes IFLOZ CNRS INSU 12000167 and ANR VMCS VULNOZ 012. Drs Simon Thornton and Dave Grant are gratefully acknowledged for careful reading of the manuscript.

\section{REFERENCES}

Antoni F. (1994) Etude des interactions entre la pollution photo-oxydante (ozone), le stress hydrique et l'enrichissement en CO2 sur le métabolisme carboné chez l'épicéa et le hêtre. Master thesis, Université Henri Poincaré Nancy 1, France: $42 \mathrm{pp}$.

Ashmore M.R. (2005) Assessing the future global impacts of ozone on vegetation. Plant, Cell and Environment, 28, 949-964.

Ashmore M.R., Emberson L., Karlsson P.E., Pleijel H. (2004) New directions: a new generation of ozone critical levels for the protection of vegetation in Europe. Atmospheric Environment, 38, 2213-2214.

Bagard M., Le Thiec D., Delacôte E., Hasenfratz-Sauder M.-P., Banvoy J., Gérard J., Dizengremel P., Jolivet Y. (2008) Ozone-induced changes in photosynthesis and photorespiration of hybrid poplar in relation to the developmental stage of the leaves. Physiologia Plantarum, 134, 559-574.

Bohler S., Bagard M., Oufr M., Planchon S., Hoffmann L., Jolivet Y., Hausman J.-F., Dizengremel P., Renaut J. (2007) A DIGE analysis of developing poplar leaves subjected to ozone reveals major changes in carbon metabolism. Proteomics, 7, 1584-1599.

Brendley B.W., Pell E.J. (1998) Ozone-induced changes in biosynthesis of Rubisco and associated compensation to stress in foliage of hybrid poplar. Tree Physiology, 18, 81-90.

Bustos D.M., Bustamante C.A., Iglesias A.A. (2008) Involvement of non-phosphorylating glyceraldehyde-3-phosphate dehydrogenase in response to oxidative stress. Journal of Plant Physiology, 165, 456-461.

Byvoet P., Balis J.U., Shelley S.A., Montgomery M.R., Barber M.J. (1995) Detection of hydroxyl radicals upon interaction 
of ozone with aqueous media or extracellular surfactant: the role of trace iron. Archives of Biochemistry and Biophysics, 319, 464-469.

Chen R.D., Gadal P. (1990) Do mitochondria provide 2-oxoglutarate needed for glutamate synthesis in higher plant chloroplasts? Plant Physiology and Biochemistry, 28, 141-145.

Citerne A., Dizengremel P., Pierre M., Queiroz O. (1989) Enzyme capacities in needles from spruce clones submitted to controlled pollution and from healthy and diseased trees. In: Bucher J., Bucher-Wallin I. (Eds), Air pollution and forest decline. EAFV, Birmensdorf, Switzerland, pp 390-392.

Conklin P.L., Barth C. (2004) Ascorbic acid, a familiar small molecule intertwined in the response of plants to ozone, pathogens, and the onset of senescence. Plant, Cell and Environment, 27, 959-970.

D’Haese D., Vandermeiren K., Asard H., Horemans N. (2005) Other factors than apoplastic ascorbate contribute to the differential ozone tolerance of two clones of Trifolium repens L. Plant, Cell and Environment, 28, 623-632.

Dalstein L., Torti X., Le Thiec D., Dizengremel P. (2002) Physiological study of declining Pinus cembra (L.) trees in southern France. Trees, 16, 299-305.

Deschaseaux A. (1997) Effets de l'ozone sur les processus de fixation du $\mathrm{CO}_{2}$ chez Populus tremula $x$ alba : approches enzymatique et isotopique (delta ${ }^{13} \mathrm{C}$ ). Master thesis, Université Henri Poincaré Nancy 1, France: 24 pp.

Di Baccio D., Castagna A., Paoletti E., Sebastiani L., Ranieri A. (2008) Could the differences in $\mathrm{O}_{3}$ sensitivity between two polar clones be related to a difference in antioxidant defense and secondary metabolic response to $\mathrm{O}_{3}$ influx? Tree Physiology, 28, 1761-1772.

Dizengremel P. (2001) Effects of ozone on the carbon metabolism of forest trees. Plant Physiology and Biochemistry, 39, 729-742.

Dizengremel P., Petrini M. (1994) Effects of air pollutants on the pathways of carbohydrate breakdown. In: Alscher R.G., Wellburn A.R. (Eds), Plant responses to the gaseous environment. Chapman and Hall, London: pp 255-277.

Dizengremel P., Sasek T.W., Brown K.J., Richardson C.J. (1994) Ozone-induced changes in primary carbon metabolism enzymes of loblolly pine needles. Journal of Plant Physiology, 144, 300-306.

Dizengremel P., Le Thiec D., Bagard M., Jolivet Y. (2008) Ozone risk assessment for plants: central role of metabolism-dependent changes in reducing power. Environmental Pollution, 156, 11-15.

Drincovich M.F., Casati P., Andreo C.S., Donahue R., Edwards G.E. (1998) UV-B induction of NADP-malic enzyme in etiolated and green maize seedlings. Plant Cell and Environment, 21, 63-70.

Fontaine V. (1999) Influence de l'ozone et de la sécheresse sur le métabolisme carboné des aiguilles de pin d'Alep (Pinus halepensis Mill.). Etude de la régulation de la phosphoénolpyruvate carboxylase. $\mathrm{PhD}$ thesis, Université Henri Poincaré Nancy 1, France.
Fontaine V., Pelloux J., Podor M., Afif D., Gérant D., Grieu P., Dizengremel P. (1999) Carbon fixation in Pinus halepensis submitted to ozone. Opposite response of ribulose-1,5-bisphosphate carboxylase/oxygenase and phosphoenolpyruvate carboxylase. Physiologia Plantarum, 105, 187-192.

Fontaine V., Cabané M., Dizengremel P. (2003) Regulation of phoshoenolpyruvate carboxylase in Pinus halepensis needles submitted to ozone and water stress. Physiologia Plantarum, 117, 445-452.

Foyer C.H., Noctor G. (2005) Redox homeostasis and antioxidant signaling: a metabolic interface between stress perception and physiological responses. Plant Cell, 17, 18661875.

Fuhrer J., Skärby L., Ashmore M.R. (1997) Critical levels for ozone effects on vegetation in Europe. Environmental Pollution, 97, 91-106.

Gaucher C., Costanzo N., Afif D., Mauffette Y., Chevrier N., Dizengremel P. (2003) The impact of elevated ozone and carbon dioxide on young Acer saccharum seedlings. Physiologia Plantarum, 117, 392-402.

Gérant D., Podor M., Grieu P., Afif D., Cornu S., Morabito D., Banvoy J., Robin C., Dizengremel P. (1996) Carbon metabolism enzyme activities and carbon partitioning in Pinus halepensis Mill. exposed to mild drought and ozone. Journal of Plant Physiology, 148, 142-147.

Gerosa G., Marzuoli R., Desotgiu R., Bussotti F., BallarinDenti A. (2009) Validation of the stomatal flux approach for the assessment of ozone visible injury in young forest trees. Results from the TOP (transboundary ozone pollution) experiment at Curno, Italy. Environmental Pollution, 157, 1497-1505.

Grünhage L., Krupa S.V., Legge A.H., Jager H.-J. (2004) Ambient flux-based critical values of ozone for protecting vegetation: differing spatial scales and uncertainties in risk assessment. Atmospheric Environment, 38, 2433-2437.

Gupta P., Duplessis S., White H., Karnosky D.F., Martin F., Podila G.K. (2005) Gene expression patterns of trembling aspen trees following long-term exposure to interacting elevated $\mathrm{CO}_{2}$ and tropospheric $\mathrm{O}_{3}$. New Phytologist, 167, 129142.

Heath R.L. (2008) Modification of the biochemical pathways of plants induced by ozone: what are the varied routes of change? Environmental Pollution, 155, 453-463.

Hodges M., Flesch V., Galvez S., Bismuth E. (2003) Higher plant NADP-dependent isocitrate dehydrogenases, ammonium assimilation and NADPH production. Plant Physiology and Biochemistry, 41, 577-585.

van Hove L.W.A., Bossen M.E., San Gabino B.G., Sgreva C. (2001) The ability of apoplastic ascorbate to protect poplar leaves against ambient ozone concentrations: a quantitative approach. Environmental Pollution, 114, 371-382.

Inclan R., Gimeno B.S., Dizengremel P., Sanchez M. (2005) Compensation processes of Aleppo pine (Pinus halepensis Mill.) to ozone exposure and drought stress. Environmental Pollution, 137, 517-524. 
Junqua M., Biolley J.P., Pié S., Kanoun M., Duran R., Goulas P. (2000) In vivo occurrence of carbonyl residues in Phaseolus vulgaris proteins as a direct consequence of a chronic ozone stress. Plant Physiology and Biochemistry, 38, 853-861.

Kangasjärvi J., Jaspers P., Kollist H. (2005) Signalling and cell death in ozone-exposed plants. Plant, Cell and Environment, 28, 1021-1036.

Karlsson P.E., Uddling J., Braun S., Broadmeadow M., Elvira S., Gimeno B.S., Le Thiec D., Oksanen E., Vandermeiren K., Wilkinson M., Emberson L. (2004) New critical levels for ozone effects on young trees based on AOT40 and simulated cumulative leaf uptake of ozone. Atmospheric Environment, 38, 2283-2294.

Karnosky D., Skelly J., Percy K., Chappelka A. (2007) Perspectives regarding 50 years of research on effects of tropospheric ozone air pollution on US forests. Environmental Pollution, 147, 489-506.

Krupa S., McGrath M.T., Andersen C.P., Booker F.L., Burkey K.O., Chappelka A.H., Chevone B.I., Pell E.J., Zilinskas B.A. (2001) Ambient ozone and plant health. Plant Disease, 85, 4-12.

Landolt W., Gunthardt-Goerg M.S., Pfenninger I., Scheidegger C. (1994) Ozone-induced microscopical changes and quantitative carbohydrate contents of hybrid poplar (Рориlus $\times$ euramericana). Trees, 8, 183-190.

Landolt W., Gunthardt-Goerg M.S., Pfenninger I., Einig W., Hampp R., Maurer S., Matyssek R. (1997) Effect of fertilization on ozone-induced changes in the metabolism of birch (Betula pendula) leaves. New Phytologist, 137, 389-397.

Langebartels C., Wohlgemuth H., Kschieschan S., Grün S., Sandermann H. (2002) Oxidative burst and cell death in ozone-exposed plants. Plant Physiology and Biochemistry, 40, 567-575.

Lefohn A.S., Laurence J.A., Kohut R.J. (1988) A comparison of indices that describe the relationship between exposure to ozone and reduction in the yield of agricultural crops. Atmospheric Environment, 22, 1229-1240.

Leitao L., Dizengremel P., Biolley J.-P. (2008) Foliar $\mathrm{CO}_{2}$ fixation in bean (Phaseolus vulgaris L.) submitted to elevated ozone: distinct changes in Rubisco and PEPc activities in relation to pigment content. Ecotoxicology and Environmental Safety, 69, 531-540.

Leterrier M., del Rio L.A., Corpas F.J. (2007) Cytosolic NADPisocitrate dehydrogenase of pea plants: genomic clone characterization and functional analysis under abiotic stress conditions. Free Radical Research, 41, 191-199.

Lütz C., Anegg S., Gérant D., Alaoui-Sosse B., Gérard J., Dizengremel P. (2000) Beech trees exposed to high $\mathrm{CO}_{2}$ and to simulated ozone levels: effects on photosynthesis, chloroplast components and leaf enzyme activity. Physiologia Plantarum, 109, 252-259.

Luwe M. (1996) Antioxidants in the apoplast and symplast of beech (Fagus sylvatica L.) leaves: seasonal variations and responses to changing ozone concentrations in air. Plant, Cell and Environment, 19, 321-328.
Matyssek R., Innes J.L. (1999) Ozone - a risk factor for trees and forests in Europe? Water, Air and Soil Pollution, 116, 199-226.

Matyssek R., Wieser G., Nunn A.J., Kozovits A.R., Reiter I.M., Heerdt C., Winkler J.B., Baumgarten M., Haberle K.-H., Grams T.E.E., Werner H., Fabian P., Havranek W.M. (2004) Comparison between AOT40 and ozone uptake in forest trees of different species, age and site conditions. Atmospheric Environment, 38, 2271-2281.

Matyssek R., Le Thiec D., Löw M., Dizengremel P., Nunn A.J., Häberle K.-H. (2006) Interaction between drought stress and $\mathrm{O}_{3}$ stress in forest trees. Plant Biology, 8, 11-17.

Matyssek R., Sandermann H., Wieser G., Booker F., Cieslik S., Musselman R., Ernst D. (2008) The challenge of making ozone risk assessment for forest trees more mechanistic. Environmental Pollution, 156, 567-582.

Müller G.L., Drincovich M.F., Andreo C.S., Lara M.V. (2008) Nicotiana tabacum NADP-malic enzyme: cloning, characterization and analysis of biological role. Plant Cell Physiology, 49, 469-480.

Musselman R.C., Lefohn A.S., Massman W.J., Heath R.L. (2006) A critical review and analysis of the use of exposureand flux-based ozone indices for predicting vegetation effects. Atmospheric Environment, 40, 1869-1888.

Noctor G. (2006) Metabolic signalling in defence and stress: the central roles of soluble redox couples. Plant, Cell and Environment, 29, 409-425.

Paoletti E., Manning W.J. (2007) Toward a biologically significant and usable standard for ozone that will also protect plants. Environmental Pollution, 150, 85-95.

Pell E.J., Eckardt N., Enyedi A.J. (1992) Timing of ozone stress and resulting status of Ribulose bisphosphate carboxylaseoxygenase and associated net photosynthesis. New Phytologist, 120, 397-405.

Pell E.J., Sinn J.P., Brendley B.W., Samuelson L., VintenJohansen C., Tien M., Skillman J. (1999) Differential response of four tree species to ozone-induced acceleration of foliar senescence. Plant, Cell and Environment, 22, 779790.

Pelloux J., Jolivet Y., Fontaine V., Banvoy J., Dizengremel P. (2001) Changes in Rubisco and Rubisco activase gene expression and polypeptide content in Pinus halepensis M. subjected to ozone and drought. Plant, Cell and Environment, 24, 123-131.

Pitcher L.H., Zilinskas B.A. (1996) Overexpression of copper/zinc superoxide dismutase in the cytosol of transgenic tobacco confers partial resistance to ozone-induced foliar necrosis. Plant Physiology, 110, 583-588.

Plöchl M., Lyons T., Ollerenshaw J., Barnes J.D. (2000) Simulating ozone detoxification in the leaf apoplast through the direct reaction with ascorbate. Planta, 210, 454-467.

Polle A., Wieser G., Havranek W.M. (1995) Quantification of ozone influx and apoplastic ascorbate content in needles of Norway spruce trees (Picea abies L. Karst.) at high altitude. Plant Physiology, 94, 312-319. 
Ranieri A., Castagna A., Padu E., Moldau H., Rahi M., Soldatini G.F. (1999) The decay of $\mathrm{O}_{3}$ through direct reaction with cell wall ascorbate is not sufficient to explain the different degrees of $\mathrm{O}_{3}$ sensitivity in two poplar clones. Journal of Plant Physiology, 154, 250-255.

Rao M.V., Davis K.R. (2001) The physiology of induced cell death. Planta, 213, 682-690.

Renaut J., Bohler S., Hausman J.F., Hoffmann L., Sergeant K., Ashan N., Jolivet Y., Dizengremel P. (2009) The impact of atmospheric composition on plants: a case study of ozone and poplar. Mass Spectrometry Reviews, 28, 495-516.

Sandermann H., Ernst D., Heller W., Langebartels C. (1998) Ozone: an abiotic elicitor of plant defence reactions. Trends in Plant Science, 3, 47-50.

Scheibe R. (2004) Malate valves to balance cellular energy supply. Physiologia Plantarum, 120, 21-26.

Schinkel H., Streller S., Wingsle G. (1998) Multiple forms of extracellular superoxide dismutase in needles, stem tissues and seedlings of Scots pine. Journal of Experimental Botany, 49, 931-936.

Sehmer L., Fontaine V., Antoni F., Dizengremel P. (1998) Effects of ozone and elevated atmospheric carbon dioxide on carbohydrate metabolism of spruce needles. Catabolic and detoxification pathways. Physiologia Plantarum, 102, 605-611.

Sen Gupta A., Alscher R.G., McCune D. (1991) Response of photosynthesis and cellular antioxidants to ozone in Populus leaves. Plant Physiology, 96, 650-655.

Srivastava H.S. (1999) Biochemical defence mechanisms of plants to increased levels of ozone and other atmospheric pollutants. Current Science, 76, 525-533.

Stitt M. (1999) Nitrate regulation of metabolism and growth. Current Opinion in Plant Biology, 2, 178-186.

Tandy N.E., Di Giulio R.T., Richardson C.J. (1989) Assay and electrophoresis of superoxide dismutase from red spruce (Picea rubens Sarg.) loblolly pine (Pinus taeda L.) and Scots pine (Pinus sylvestris L.). Plant Physiology, 90, 742-748.
Tausz M., Grulke N.E., Wieser G. (2007) Defense and avoidance of ozone under global change. Environmental Pollution, 147, 525-531.

Turcsanyi E., Lyons T., Plöchl M., Barnes J. (2000) Does ascorbate in the mesophyll cell walls form the first line of defence against ozone? Testing the concept using broad bean (Vicia faba L.). Journal of Experimental Botany, 51, 901-910.

Wieser G., Matyssek R. (2007) Linking ozone uptake and defense towards a mechanistic risk assessment for forest trees. New Phytologist, 174, 7-9.

Wild A., Schmitt V. (1995) Diagnosis of damage to Norway spruce (Picea abies) through biochemical criteria. Physiologia Plantarum, 93, 375-382.

Willekens H., van Camp W., van Montagu M., Inze D., Langebartels C., Sandermann H. (1994) Ozone, sulfur dioxide, and ultraviolet B have similar effects on mRNA accumulation of antioxidant genes in Nicotiana plumbaginifolia L. Plant Physiology, 106, 1007-1014.

Wingsle G., Mattson A., Ekblad A., Hällgren J.-E., Selstam E. (1992) Activities of glutathione reductase and superoxide dismutase in relation to changes of lipids and pigments due to ozone in seedlings of Pinus sylvestris L. Plant Science, 82, 167-178.

Wittig V.E., Ainsworth E.A., Long S.P. (2007) To what extent do current and projected increases in surface ozone affect photosynthesis and stomatal conductance of trees? A metaanalytic review of the last 3 decades of experiments. Plant, Cell and Environment, 30, 1150-1162.

Wittig V.E., Ainsworth E.A., Naidu S.L., Karnoski D.F., Long S.P. (2009) Quantifying the impact of current and future tropospheric ozone on tree biomass, growth, physiology and biochemistry: a quantitative meta-analysis. Global Change Biology, 15, 396-424.

Zheng Y., Lyons T., Ollerenshaw J.H., Barnes J.D. (2000) Ascorbate in the leaf apoplast is a factor mediating ozone resistance in Plantago major. Plant Physiology and Biochemistry, 38, 403-411. 